\title{
Monitoring mass movements and natural hazard in the northern parts of Srem loess plateau in Serbia
}

\section{Mesaroš Minučer, Dragoslav Pavić, Slobodan Seferović}

\begin{abstract}
The Fruška Gora mountain represents an outstanding natural and economic resource, an area of rich biodiversity, cultural and touristic importance. It is situated along very important regional and local transport routes. The northern slopes of the mountain mostly covered with quaternary sediments constitute the north most region of the Srem loess plateau. The loose quaternary sediments above lacustrine deposits (sand, clay) and the continuous strong erosive force of the Danube undermining the sediment base result in mass movements along the riverbank. Although precise modeling and prediction of mass movements is often uneconomic and require very detailed knowledge of involved processes due to their abrupt and complex nature, analysis of readily available data with GIS can give satisfactory results for planning and reducing the impact of damages caused by mass movements. In this paper we examine the possibilities of mass movement monitoring in the area of northern Fruška gora using methods of remote sensing and geomatics.
\end{abstract}

Keywords: Fruška Gora, Srem loess plateau, geomorphology, GIS, remote sensing

Department of Geography, Tourism And Hotel Management, Faculty of Sciences, University of Novi Sad, Trg Dositeja Obradovića 3, 21000, Novi Sad

\section{Introduction}

Fruška Gora is located just a few kilometers south of Novi Sad, the second-largest city in Serbia. This gently sloped, isolated mountain with its greatest height of $539 \mathrm{~m}$ dominates the surrounding lowlands. Large areas of the mountain are covered with loess, constituting the Srem loess plateau, which is especially susceptible to mass movements, erosion, and soil degradation.

Important transportation routes, like the pan European corridor 1oB (Belgrade take precautionary measures. In monitoring and management of larger areas remote sensing and GIS provides an invaluable aide.

\section{Study Area Description}

The study area encloses the northern slope of Fruška gora, extending about $60 \mathrm{~km}$ in the E-W direction, and a maximum of 10 kilometers in N-S direction. The western limit of the area is along the road between Vizić and Neštin along the Croatian bor$\mathrm{der}^{1}$. From the north the area is bounded

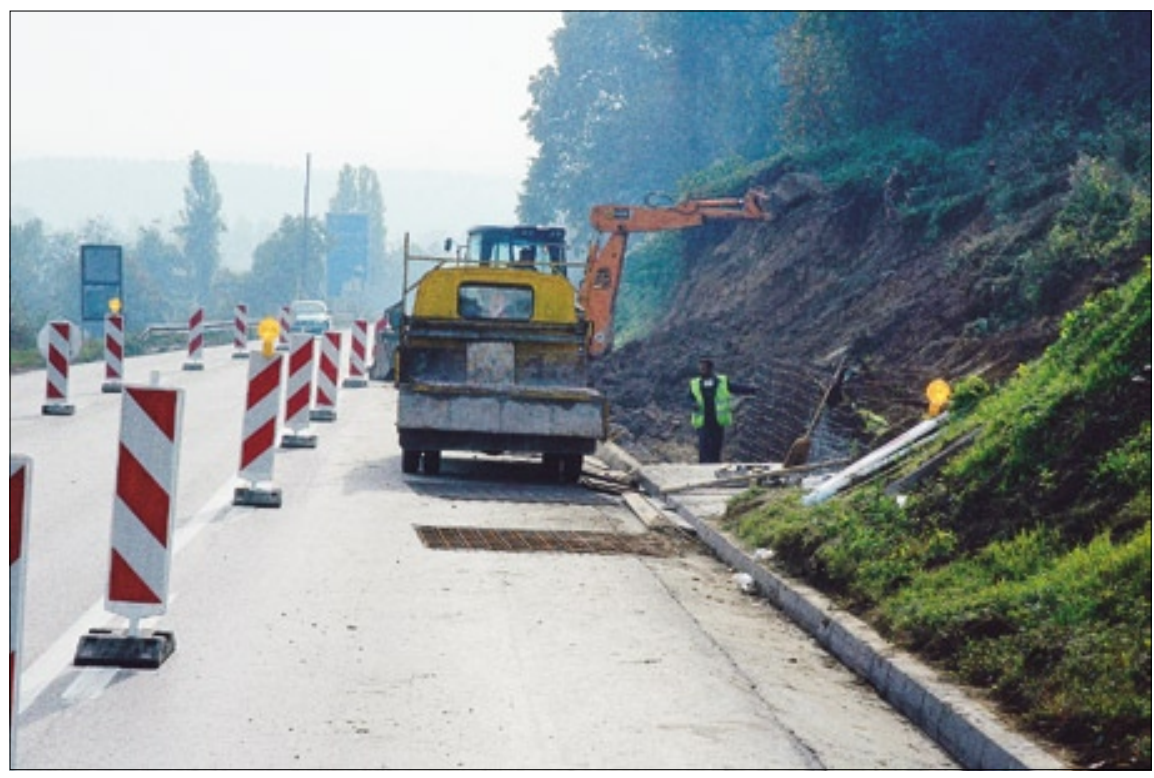

Figure 1 Repair work on a section of the Beograd-Novi Sad regional motorway near Sremski Karlovci (18.10.2007)

- Budapest), the Belgrade - Novi Sad railway and regional motorway, and the Sremska Kamenica - Vukovar regional road are crossing over unstable terrains trough the mountain, often prompting costly repairs, traffic jams and delays.

Using satellite stereographic photographs and other methods of spatial analysis the scale of changes caused by the mass movements can be evaluated, and the GIS model can be utilized in further monitoring and planning. This decision support system gives an opportunity to quickly identify zones of increased risk, and to by the Danube and from south by the ridge of the mountain. To the east it extends to the loess cliffs above the Danube at Stari Slankamen. This area was selected primarily for its high number of observable slides and slumps, and because they pose a considerable natural hazard, and caused damages in previous periods of activity.

1 The Fruška gora extends further accross in Croatia on the west, near the Telek cliff in the vicinity of Šarengrad (Bukurov, B.) . According to other views it reaches as far as Vukovar to the west. 


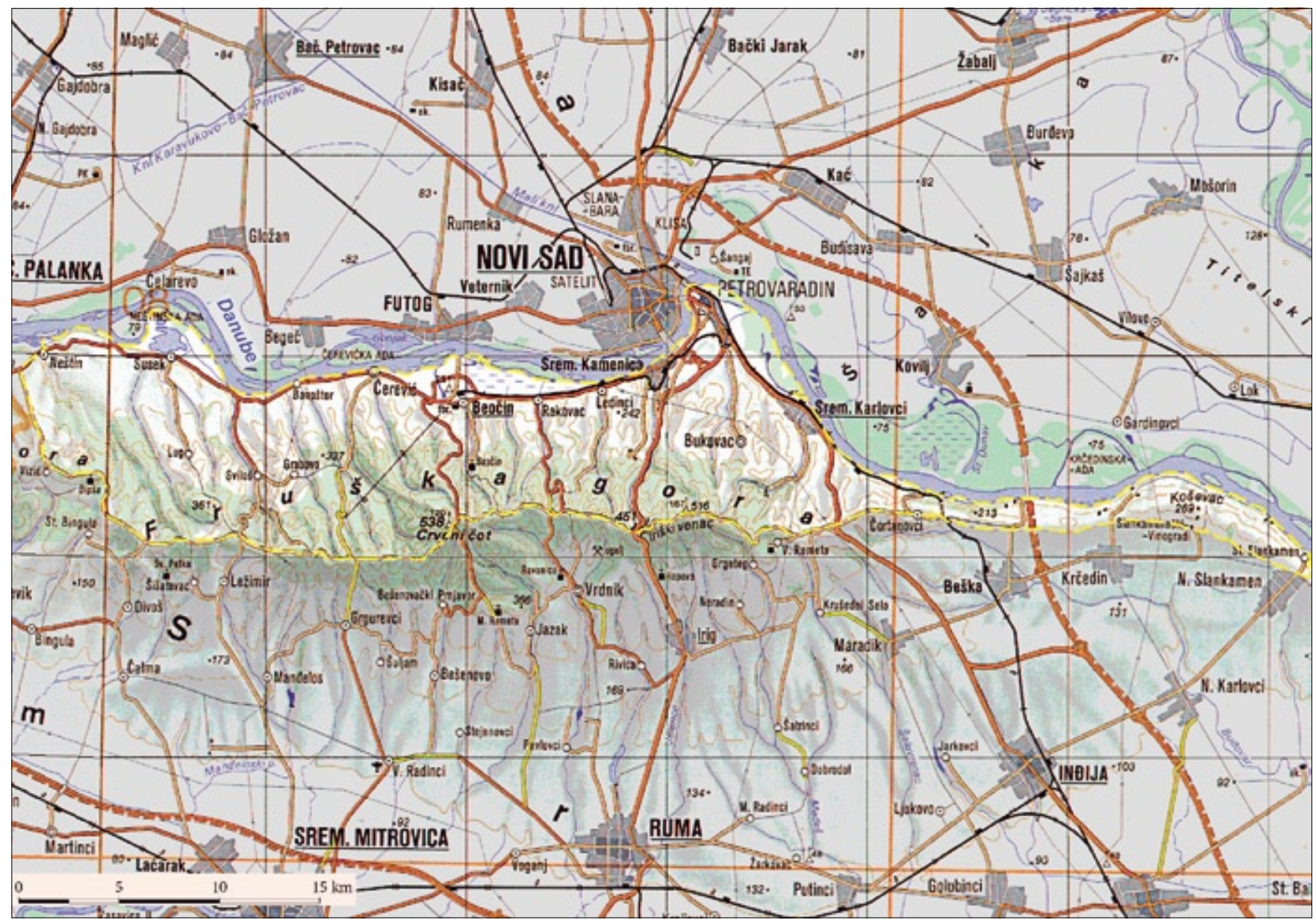

Figure 2 Map of the selected study area

The northern part of the mountain is heavily influenced by the erosive force of Danube which is constantly undermining the loose sediment base. The terrain covered with loess sediments is susceptible to increased erosion, especially on the steeper northern slopes of Fruška Gora.

The Srem loess plateau represents a geomorphologic unit which encloses the central massif from all sides. It is dissected by fluvial erosion processes from numerous streams in longitudinal direction coming from the central ridge. This is especially characteristical in the central northern parts of the plateau on the northern slopes of Fruška gora, where the loess areas appear in form of smaller partitions separated by stream valleys.

\section{Materials and Methods}

Readily available and affordable sources were selected for estimation of natural hazard spatial distribution and the morphologic characteristics of landslides. Detailed topographic maps (1:25.00o) with an equidistance of 10 meters were used for digital elevation model (DEM) generation from contours and elevation points. For this purpose the TopoToRaster function was used in ArcGIS9.2, and a DEM with a resolution of 10 meters was generated for the whole area.

A stereographic satellite image from February 1969. (Corona, 3m resolution) was used to obtain DEM ( $5 \mathrm{~m}$ cell size) for comparison with the recent situation. The DEM was generated with ERDAS Imagine OrthoBase (Mészáros et al., 2006).
The use of Digital Elevation Models (DEMs) to observe topographic attributes, such as slope aspect and steepness, allows researchers to comprehensively examine the variables affecting landslide occurrence in a study area. DEMs are routinely used to calculate aspect for landslide susceptibility studies (Dai et al., 2001, Lee et al., 2002).

Digital geologic map of 1:100.00o was used to identify geologically susceptible terrain for mass movements.

Changes in the density of forest cover were estimated using aerial and satellite imagery from various periods, as well as the database of the Fruška Gora National Park forestry department.

Traditional methods for landslide hazard assessment were used, involving field observation, high resolution aerial and sat-

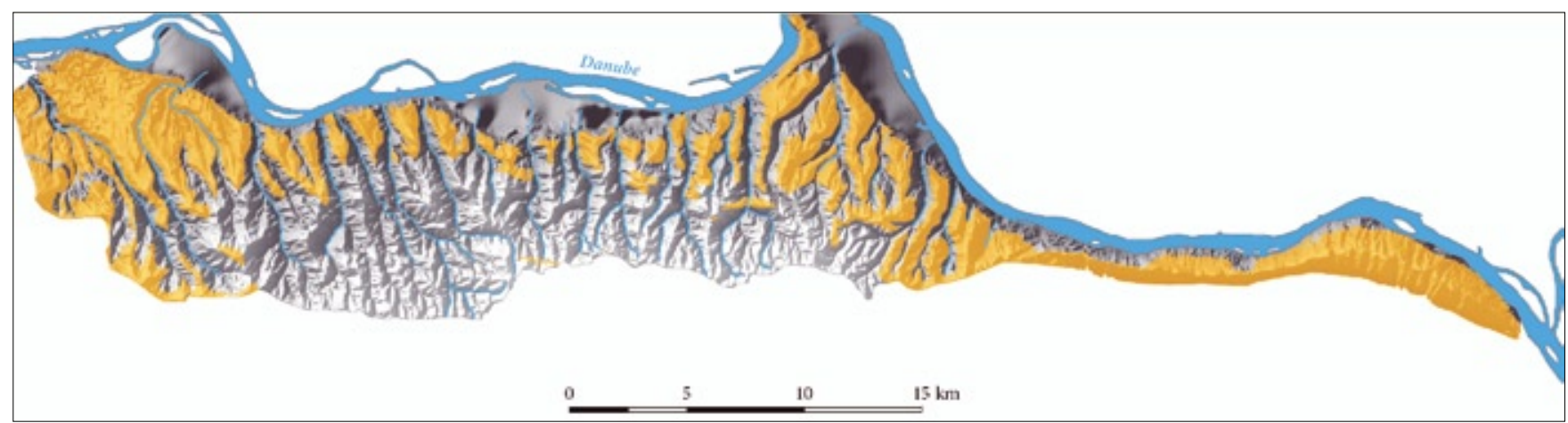

Figure 3 The northern parts of the Srem loess plateau 


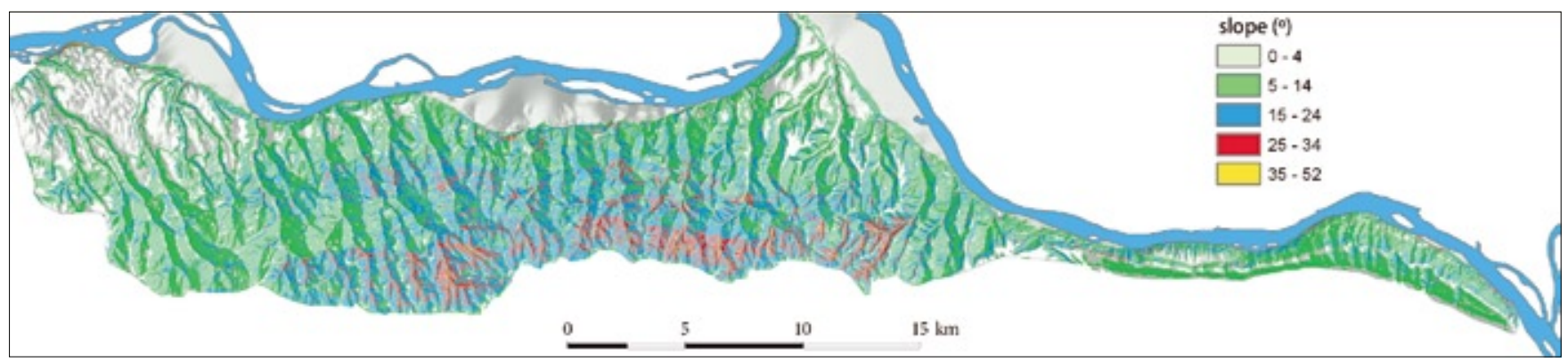

Figure 4 Map of slopes at northern

ellite imagery, thematic maps, DEM/slope maps and an inventory of past landslides. (Janet et al., 2005)

\section{Results}

The most useful direct indicators of landslide susceptibility are considered to be evidence of past landslides as well as tension cracks and other detectable earth movement. Therefore, the simplest type of landslide hazard assessment comprises an inventory of previous landslides and signs of mass movement, based on the premise that an area with past landslides is landslide prone and has a high probability of new landslides. (Odajima et al., 1998).

An inventory of past landslides on the northern slopes of Fruška gora was created based on geologic maps and terrain observations. The inventory contains morphologic and temporal attributes of the known mass movements.

The remote analysis of landslides from raster data sources with a resolution greater than $5 \mathrm{~m}$ which are often available can provide some basic morphometric information. The complete northern side of Fruška gora extending along the right bank of the Danube has numerous large-scale active and fossile landslides. The surficial forms created by mass movements have the greatest concentration along the contact zone between the right bank of the Danube and the loess plateau, and are absent only in the lower part of valleys on the confluence of streams and the Danube, mainly due to the flatness of terrain. (Lazarević, 200o) Mass movements are also frequently present farther away from the Danube, on the steep slopes of stream valleys, composed from alluvial sediments. The areas covered with loess on the northern parts of Fruška gora represent an excellent example of a large area affected by mass movements, where the application of GIS and remote sensing provide an invaluable support of monitoring mass movements.

Although these methods have some serious cost/benefit-related limitations, mainly due to the insufficient resolution of images and digital terrain models (DTM), the advantages of GIS in efficient data storage, query, analysis and visualization make it an irreplaceable tool in studying surficial movements over large areas.
The size of the slide-affected surface can be often visually established and measured, with basic volumetric and area information obtained as well. With the exception of fosile landslide areas under dense forests, larger mass movements are usually clearly recognizable on high resolution photographs.

Using the technique of image draping of an area on a DEM, in combination with stereographic $3 \mathrm{D}$ view provides researchers with the best method of remote visual inspection of landslides. Smaller cracks which can be a sign of an impending renewed activity cannot be detected using coarser resolutions, and require a direct field observation.

Cross-sections provide insight in the evolution of landforms shaped by mass movement. Cross sections can be easily constructed on DEM and DTM. Some most characteristic areas were selected, to demonstrate this method on the northern part of the Srem loess plato.

\section{Mapping the Spatial Distribution of Mass Movement Susceptibility}

Various methods have been applied to regional landslide susceptibility assessment worldwide in the last twenty years, including deterministic, heuristic and statistical
Approaches. The methods were reviewed by Carrara et al. (2001), Chung and Fabbri (2003, 2005), Remondo et al. (2003) and Van Westen et al. (2003), who identified many deficiencies in large number of landslide susceptibility maps. (Terlien, M.T.J., et al. 1995.)

Many of these limitations cannot be avoided, when using easily accessible and affordable data sources. For the analysis of the spatial distribution of mass movement susceptibility in the study area of northern Srem loess plateau, the following factors were taken into consideration:

slope, measured from DEM and DTM obtained from a topographic map and satellite image. Areas with slopes exceeding $5^{\circ}$ were considered to be susceptible to mass movements.

spatial distribution of loess sediments, which in combination with lacustric deposits (sand and clay) in the base can be prone to mass movements

locations of previous landslides. The Danube is continuously undermining the foot of mountain, causing the lowering of the erosion base and slope instability, so the locations of previous movements can be considered a good indicators of future activity.

forest areas were considered a modifying/stabilizing factor.

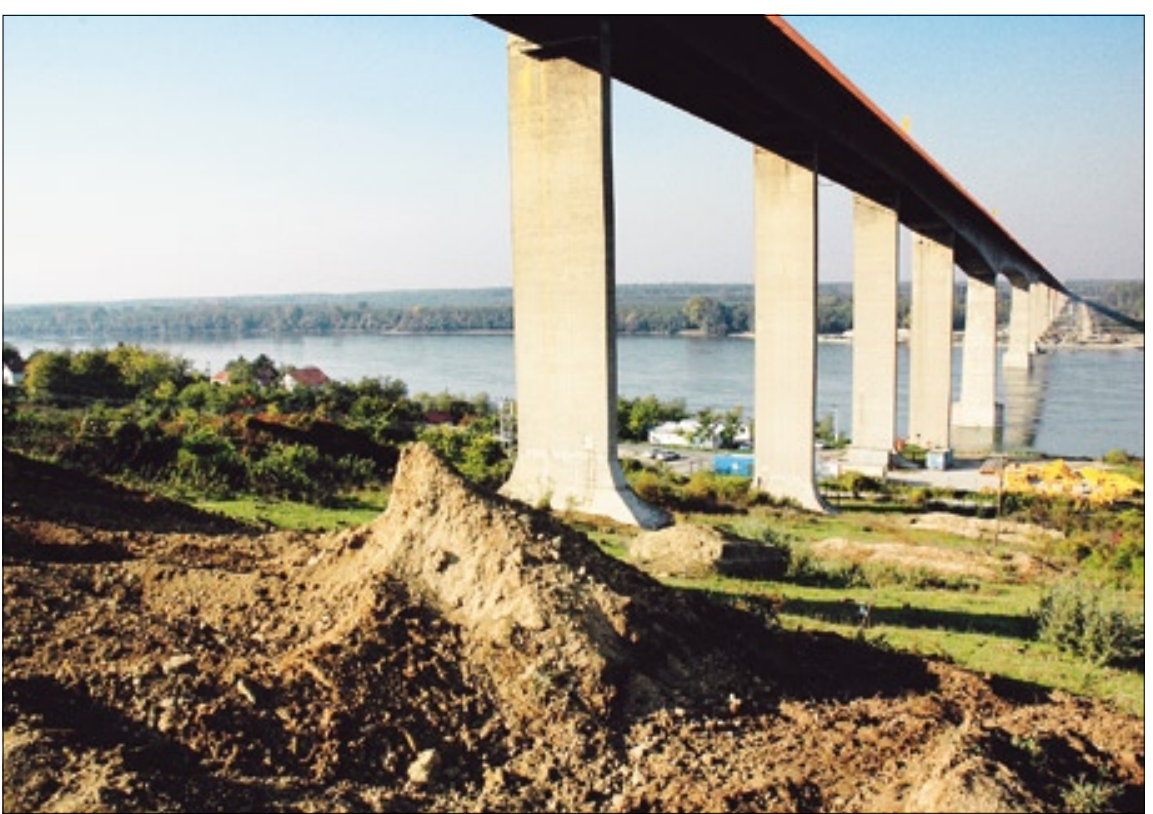

Figure 5 The southern edge of the E75 highway bridge near Beška (18.10.2007) 


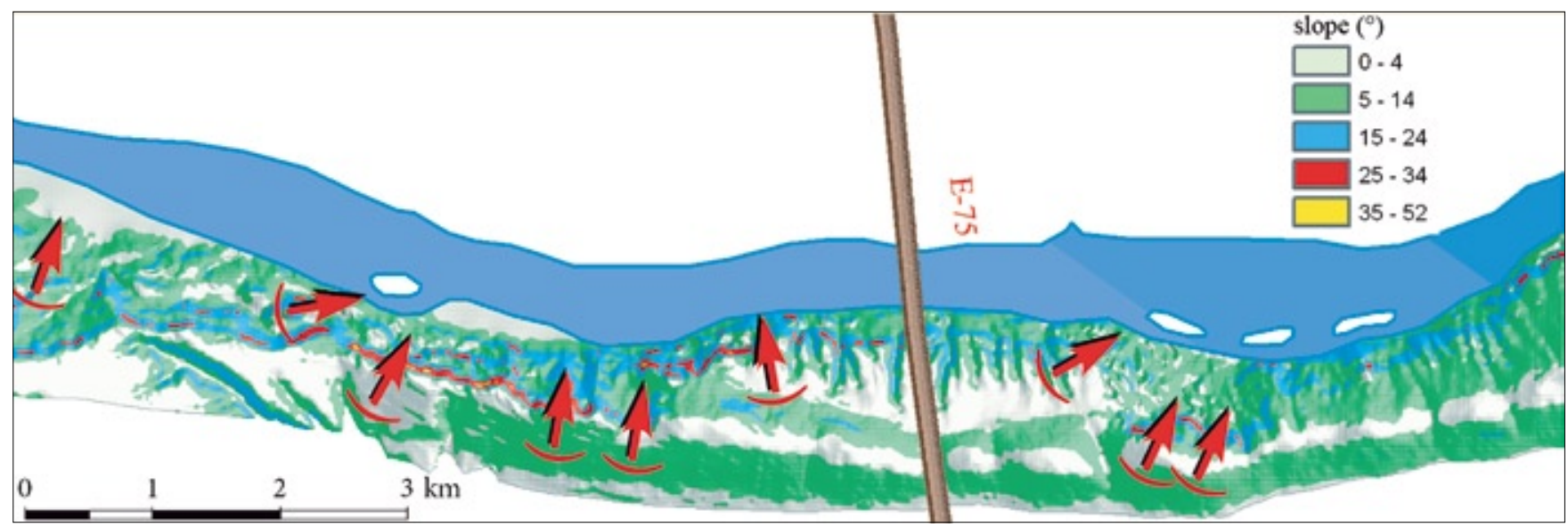

Figure 6 Landslides around the E75 highway bridge

This simplified method provides a rough assessment of mass movement susceptibility, and constitutes a basis for further research and model refinement. The insufficient quality and quantity of necessary input data for more exact modeling of land- have been prevented with a more careful

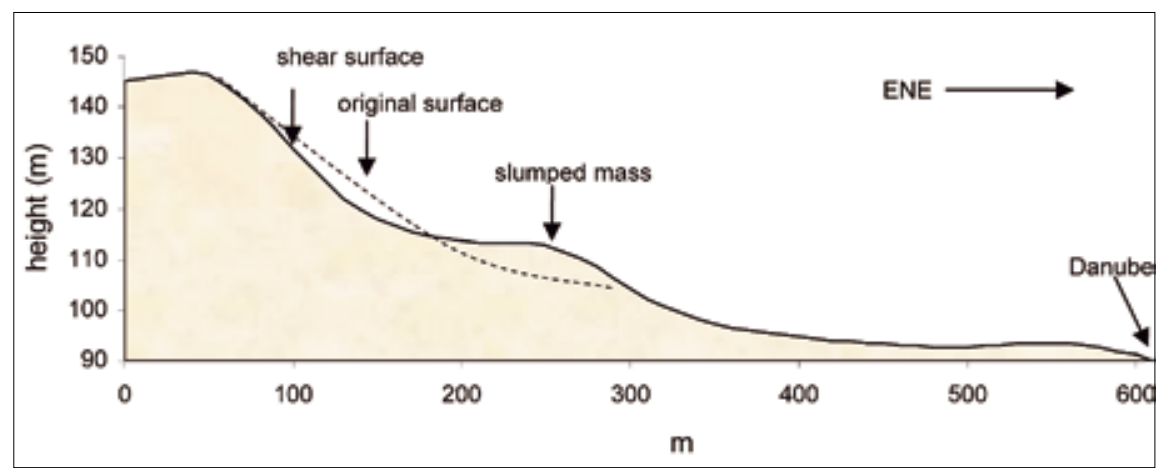

Flgure 7 Cross section, obtained from a DEM with 10m resolution, showing typical elements of landslide

slides justifies the applied simple methodology. More sophisticated analysis would not necessarily yield more useful information.

Using the above mentioned methodology, areas with increased landslide susceptibility were identified.

One of the areas identified with strong mass movement susceptibility is located near the bridge on the E75 route, which is a part of the Pan European Corridor $10 \mathrm{~B}$ (Belgrade - Budapest). This site had been active in previous periods, and constitutes a further natural hazard. Another bridge is being built to the east next to the existing one, for the second lane of E75 highway.

More detailed examination of the underlying terrain is also being conducted, and a solution sought for the slope stabilization.

\section{Conclusion}

Precise modeling and prediction of surficial mass movements requires great investment, which is in most cases uneconomical, due to the complex nature and correlation of different factors influencing landslides.

Mass movements often cause serious disruptions and damages, which could planning and monitoring.

The studied area of the northern Srem loess plateau is especially prone to increased natural hazard, caused by specific geologic, geomorphologic, and hydrologic, vegetation conditions and human activities. Important transport routes are crossing trough areas with increased landslide susceptibility, and are often affected by mass movements.

The analyzed data sources which were readily available and cost effective proved a very good basis for further research of these areas. Basic information was successfully obtained from topographic and satellite images about the spatial distribution, morphology and evolution of larger scale mass movements. A coarse map of landslide susceptibility was constructed from the available data with a simplified methodology. This map can give in combination with further observation a clear direction for further more detailed research and preventive measures.

A more detailed survey of the geologic, vegetation and anthropogenic attributes is needed, especially in areas identified as high risk zones.

\section{Acknowelagents}

This work is supported by the Ministry of science, Republic of Serbia (grant 146019).

\section{References}

Brardinoni F., Slaymaker O., Hassan M.A. 2003. Landslide inventory in rugged forested watershed: a comparison between air photo and field survey data. Geomorphology 54, 179- 196.

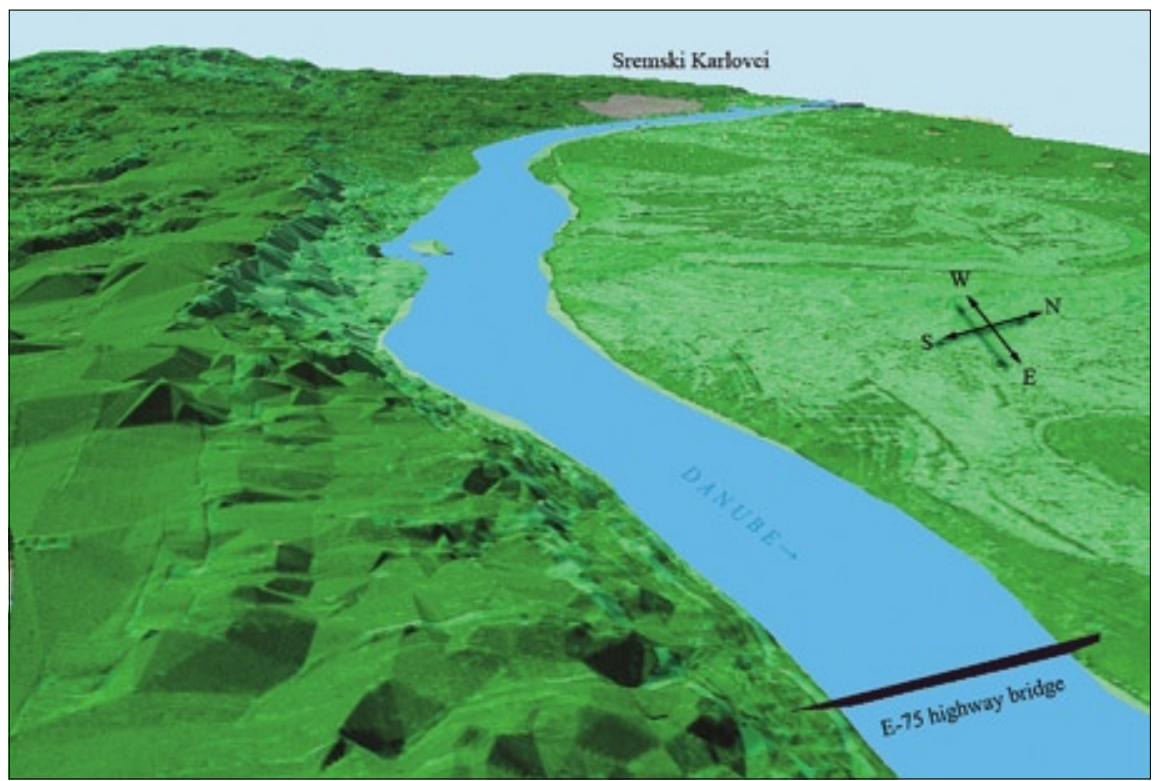

Figure 8 Satellite image draped over the DTM, showing typical landforms for mass movements 
Carrara A., Cardinali A., Guzzetti F., Reichenbach P. 2001. GIS based techniques for mapping landslide hazard. Research Centre for Informatics and Telecommunication Systems, National Research Council. [URL:] http://deis158.deis.unibo.it/gis/chapto.htm (2005-02-15).

Chung C.-J.F., Fabbri A. 2003. Validation of spatial prediction models for landslide hazard mapping. Natural Hazards 30, 451-472.

Chung C.-J.F., Fabbri A., 2005. Systematic procedures of landslide hazard mapping for risk assessment using spatial prediction models. In: Glade, T., Anderson, M.G., Crozier, M.J. (Eds.), Landslide Hazard and Risk. John Wiley \& Sons, New York, 139-174.

Dai F. C., C. F. Lee, J. Li, and Z. W. Xu. 2001. Assessment of Landslide Susceptibility on the Natural Terrain of Lan- tau Island, Hong Kong. Environmental Geology 40, 381-391.

Lee Saro, Ueechan Chwae, and Kyungduck Min. 2002. Landslide susceptibility mapping by correlation between topography and geological structure: the Janghung area, Korea. Geomorphology $46,149-162$

Malamud B.D., Turcotte D.L., Guzzetti F., Reichenback P., 2004. Landslide inventories and their statistical properties. Earth Surface Processes and Landforms 29, 687-711.

Mészáros M., Szatmári J., Tobak Z., Mucsi L. 2006. Digitális domborzatmodellek elöállítása és alkalmazása sztereo corona ürfelvételek alapján, Geodézia és Kartográfia 4/2006, Magyar Földmérési, Térképészeti és Távérzékelési társaság, Budapest, 30-35
Nichol E.J., Shaker A., Wong M.S. 2005. Application of high-resolution stereo satellite images to detailed landslide hazard assessment. Geomorphology 76, 68-75

Odajima T., Tsuchida S., Yamaguchi Y., Kamai T., Siagian Y.O.P. 1998. GIS and remote sensing based analysis of landslide hazards in Cianjur, West Java, Indonesia. Proceedings of International Symposium on Application of Remote Sensing and Geographic Information System to Disaster Reduction (ITIT International Symposium), 3-4 March 1998, 185- 190.

Terlien M.T.J., Van Westen C.J., Van Asch T.W.J. 1995. Deterministic modeling in GIS-based landslide hazard assessment. In: Carrara, A., Guzzetti, F. (Eds.), Geographical Information System in Assessing Natural Hazards. Kluwer, Dordrecht, 57-77. 